\title{
盲学校に近接した公園の分析と評価に関する研究
}

\section{A Study on the Analysis and Evaluation of the Park Adjacent to the School for the Blind}

永松 義博* 阿部 香織* 岩㴊由生子*

Yoshihiro NAGAMATU Kaori ABE Yukiko IWABUCHI

\begin{abstract}
摘要 : 盲学校に近接した公園を視覚障害者がどう利用するかについて，盲学校に依頼したアンケート による調查を行った。アンケートの集約から，多くの盲学校が公園利用を望んでいることが明らかに なった。公園を利用するためには盲学校の近くに公園があること、そして公園までの経路の安全性な どが重要な条件であった。盲学校の生徒に利用される公園の特徵は, 公園の広い空間, 公園の位置か わかりやすいこと，そして公園に多くの植物があることなどである。さらに，盲学校の生徒にとって

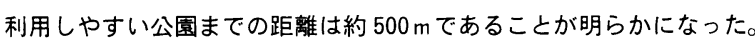

\section{1.はじめに}

近年，高龄者や身体障害者にも生活しやすい都市づくりの必要 性が叫ばれ，それに伴い街路空間や公共施設等の地域環境も見直 され改善されつつある。公園緑地の分野でも「緑の空間」のバリ アフリー化やユニバーサルデザイン化も進んでいる。障害者の外 部空間づくりの先駆的な取り組みもはじまり，計画・デザイン・ 整備方針のガイドラインとして「バリアフリー緑の空間計画」”。 「人にやさしい公園づくり」 $\rfloor^{2)}$ 「「長寿社会に対応する公園」3) ・ 「バリアフリーの景」ややや゙リアフリー緑地環境設計マニュアルの 「ケアガーデン $\rfloor^{5)}$ ，公園施設の計画・手法についてまとめた「み んなのための公園づくり」昼）等がある。しかし，これらは高齢者 や肢体不自由者の車椅子による公園利用を想定した整備項目が多 く，視覚障害者の利用を主にした整備方針は少ない。

視覚障害は環境の変化等の情報を得にくく，行動が著しく制限 されるため,このようなハンディへの施策が重要である。しかし， 実際には基礎的資料も極めて少ないのが実状である。これまでの 研究で, 視覚障害者の戸外活動への志向性は高く, 集団的な遊び で占められていること”，また組織的で活動的なクラブの入部率 が高いことや彼らの日常の遊びは基本的には盲学校や盲人施設で の友人との交友を伴って展開していることを報告した ${ }^{8)}$ 。本研究 は，これら前例を参考にしながら盲学校に近接した公園の利用に 焦点を当てて，その公園利用の現況を明らかにするものである。 視覚障害者が公園を日常的に利用するようになるための資料や, 公園の利用状況などの掌握を試みた。その結果から配慮を必要と する事柄について考察をした。

\section{2. 調查方法}

調査は全国の既設盲学校 71 校のすべてを対象とし，盲学校と しての公園の利用状況と既存公園に対する要望等についてのアン ケートを行った。アンケートは現地での面談と郵送によって回答 を得た。また地図上で，それぞれの盲学校を中心として $1 \mathrm{~km}$ 圈内 に含まれる公園を，「隣接」「「100 m圈内」，「100〜 $250 \mathrm{~m}$ 圈内」,

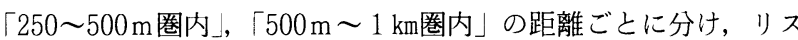
卜を作成した。そして，盲学校が利用している公園と照合し，利 用状況についての情報を得た。地図上で位置のわからない公園に ついては，各市町村へ問い合わせて補った。調查内容については, 宮崎県立盲学校から多くの助言を頂いた。
調查は，1999 年 9 月～12 月に実施し，調查対象校 71 校加ら 100\%の回答を得た。

\section{表 -1 盲学校の在籍者数と公園利用の有無}

\begin{tabular}{|c|c|c|c|}
\hline 在籍者数 & 利用する & 利用しない & 合 計 \\
\hline $1 \sim 20$ 人 & 7 & 1 & 8 \\
\hline $21 \sim 40$ 人 & 15 & 7 & 22 \\
\hline $41 \sim 60$ 人 & 16 & 6 & 22 \\
\hline $61 \sim 80$ 人 & 8 & 2 & 10 \\
\hline $81 \sim 100$ 人 & 5 & 1 & 6 \\
\hline $101 \sim 200$ 人 & 3 & 0 & 3 \\
\hline 合 計 & $\overline{54}$ & 17 & 71 \\
\hline
\end{tabular}

\section{3. 調査結果}

\section{（1）盲学校の公園利用の実態}

表一 1 は，調査校の在籍者数と公園利用の有無を示したもので ある。在籍者が $21 \sim 40$ 人と $41 \sim 60$ 人の学校が最も多い。101 人 以上の児童・生徒が在籍する盲学校は少ない。この中で公園を利 用している学校は 54 校で，残り 17 校は利用していなかった。公 園利用之盲学校の在籍者数の関係をみると，児童・生徒数が多い 盲学校も公園を利用しており，利用する率について，利用状況と 在籍者数には密接な関係はみられないが，利用しない率では在籍 者数が 20 人以下か 60 人を越えて多くなるにつれて減少する傾向 がみられる。

(1)公園までの距離と利用頻度

公園を利用している盲学校 54 校に対し，学校から利用する公 園までの距離と，公園の利用頻度についてたずねた結果を表一2 に示す。ほとんどの盲学校が利用する公園は「250m圈内」,「500 $\mathrm{m}$ 圈内」であり, 次いで $「 1 \mathrm{~km}$ 圏内」, 「1 km以上」と回答した。 公園を利用している盲学校の説明によると “約 $250 \mathrm{~m}$ の距離は 5 ～10 分程度で移動できる”ということである。当初利用される 之考えた，隣接・ $100 \mathrm{~m}$ 圈内の近距離にある公園の利用は少ない。 利用頻度については，〔週に数回，週に 1 回〕之頻繁に利用し ている学校は 31 校,〔年に数回・年に 1 回〕と利用の少ない盲学 校は 23 校,これらの中間の利用頻度にあたる〔月に $1 \sim 2$ 回〕 の利用を行う盲学校は 28 校である。

距離と利用頻度の関係を見ると,「月に $1 \sim 2$ 回」以上の頻繁 
に利用される公園は 250〜 500 mがほとん どである。また，年 に 1 回, 数回の公園 利用では遠距離の公 園になり，距離と利 用頻度で二極化する 傾向にある。

(2)公園の利用時間と 利用時間帯

公園の利用時間を

表一 3 に示す。この結果から，公園を利用する時間は「30 分程 度」と「1時間程度」が多い。また，公園を利用する時間帯をみ たのが表一 4 であるが，最も多いのは「授業中」である。この場 合，児童・生徒は授業時間内に学校と公園を往復しなければなら ないため，当然利用時間は 30 分，または 1 時間と限られてくる。 (3)公園の利用形態

公園の利用形態をみたものが表一 5 である。公園利用の内容は 小学部, 中学部, 高等部之高学年になるに伴いその種類が少なく なっている。小学部，中学部，高等部に共通して多いのは，「遊 具遊び」「散步」,「歩行訓練」である。これ以外に，小学部は 「自然観察」や「植物採集」など公園を遊びの場，または自然に 触れて親しむ場として主に利用している。中学部，高等部では小 学部のような遊びや観察が中心となった利用は減り，特に高等部 では「ソフトボール」や「バスケットボール」,「グランドゴルフ」 など，多様な運動をするための利用が増えている。 表－２＼cjkstart公園までの距離と公園の利用頻度（複数回答）

\begin{tabular}{|c|c|c|c|c|c|c|}
\hline & 週に数回 & 週に1回 & 月に1 2回 & 年に数回 & 年に1回 & 合 計 \\
\hline 隣接 & 2 & 0 & 0 & 0 & 0 & 2 \\
\hline 100m圈内 & 2 & 1 & 0 & 0 & 0 & 3 \\
\hline 250m圈内 & 8 & 5 & 6 & 1 & 0 & 20 \\
\hline 500m圈内 & 6 & 4 & 13 & 1 & 0 & 24 \\
\hline $1 \mathrm{~km}$ 圏内 & 1 & 0 & 4 & 10 & 1 & 16 \\
\hline $1 \mathrm{~km}$ 以上 & 0 & 2 & 5 & 8 & 2 & 17 \\
\hline 合 計 & 19 & 12 & 28 & 20 & 3 & \\
\hline
\end{tabular}

表 -3 公園の利用時間（複数回答）

\begin{tabular}{|l|r|}
\hline (1)30分程度 & 24 \\
\hline$(2) 1$ 時間程度 & 24 \\
\hline$(3) 2$ 時間程度 & 9 \\
\hline$(4)$ 半日 & 7 \\
\hline$(5) 1$ 日 & 1 \\
\hline$(6)$ その他 & 1 \\
\hline
\end{tabular}

(単位:学校数)

表一 4 公園を利用する時間帯（複数回答）

\begin{tabular}{|l|r|}
\hline (1)放課後 & 7 \\
\hline (2) 昼休み & 1 \\
\hline (3) 日祭日 & 1 \\
\hline (4) 長期休暇 & 1 \\
\hline (5)授業中 & 46 \\
\hline (6)その他 & 9 \\
\hline
\end{tabular}

(単位: 学校数)

表 -5 公園の利用形態（複数回答）

\begin{tabular}{|c|c|c|c|}
\hline & 小学部 & 中学部 & 高等部 \\
\hline 遊 ひ & $\begin{array}{l}\text { 遊具遊ひ }(36) \\
\text { ボール遊ひ }(3) \\
\text { ゲーム遊ひ }(2) \\
\text { 水遊び(2) } \\
\text { アスレチック遊び } \\
\text { ボランティアとの遊ひ } \\
\text { その他の遊ひ } \\
\end{array}$ & $\begin{array}{l}\text { 遊具遊び }(13) \\
\text { ボール遊び(2) } \\
\text { その他の遊ひ(2) }\end{array}$ & $\begin{array}{l}\text { 遊具遊び(5) } \\
\text { その他の遊び }\end{array}$ \\
\hline 運 動 & $\begin{array}{l}\text { 歩行訓練(養護訓練)(16) } \\
\text { 散歩 }(15) \\
\text { 体育の授業 (3) } \\
\text { 遠足 (3) } \\
\text { 野球 (2) } \\
\text { 持久走 } \\
\text { 一輪車 } \\
\text { 体カつくり }\end{array}$ & 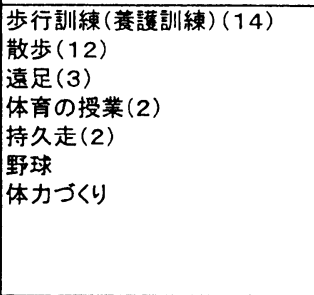 & $\begin{array}{l}\text { 歩行訓練(養護訓練)(8) } \\
\text { 散歩 }(7) \\
\text { 体育の授業 (4) } \\
\text { 遠足 }(2) \\
\text { 野球 } \\
\text { ソフトボール } \\
\text { ハススケットボール } \\
\text { ゲランドゴルフ } \\
\text { フライングディスク } \\
\text { 体カつくり }\end{array}$ \\
\hline 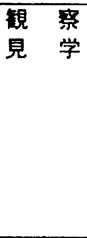 & $\begin{array}{l}\text { 自然钼察(9) } \\
\text { 理科の授業(钼祭) (4) } \\
\text { 植物探集(落ち葉ひろい等)(4) } \\
\text { 図エの授業(スケッチ)(2) } \\
\text { 社会の授業(社会見学)(2) } \\
\text { 花見(2) } \\
\text { 自然散策 } \\
\text { 公園施設の探検 }\end{array}$ & $\begin{array}{l}\text { 自然観察(6) } \\
\text { 理科の授業(钼察)(2) } \\
\text { 植物探菓 } \\
\text { 図エの授莱(スケッチ) } \\
\text { 汽車見学 } \\
\text { 花見 } \\
\text { 自然散策 }\end{array}$ & $\begin{array}{l}\text { 花見(2) } \\
\text { 自然钼察 } \\
\text { 理科の授業(钼察) } \\
\text { 汽車見学 }\end{array}$ \\
\hline その他 & $\begin{array}{l}\text { 休䚋(歩行訓練の目的地)(4) } \\
\text { 学校行事 (2) } \\
\text { イベント参加 } \\
\text { 避難訓練 } \\
\text { 清㛿活動 } \\
\text { 公園利用についての学習 } \\
\text { 自立活動 } \\
\text { レクリエーション } \\
\text { 体験学習 } \\
\text { 生活の授業 } \\
\text { 家庭科の授業 }\end{array}$ & $\begin{array}{l}\text { 休憩(歩行訓練の目的地)(3) } \\
\text { 学校行事 } \\
\text { イベント参加 } \\
\text { 避難訓練 } \\
\text { 清掃活動 } \\
\text { 奉仕活動 } \\
\text { 自立活動 } \\
\text { 野外授業 } \\
\text { 俳句づくり } \\
\text { 生活の授業 }\end{array}$ & $\begin{array}{l}\text { 休䣸(步行訓練の目的地)(2) } \\
\text { 学校行事 } \\
\text { イベント参加 } \\
\text { 避難訓練 } \\
\text { レクリエーション } \\
\text { 奉仕活動 } \\
\text { 自立活動 } \\
\text { 野外授業 } \\
\text { 俳句つくり }\end{array}$ \\
\hline
\end{tabular}

注）（）内は回答校数 
(4)利用している公園の特徴

利用している公園の特徴を表一 6 に示した。盲学校が利用して いる公園は「遊べる場所が広い」，「遊具が多い」等，遊びの空間 をもつことが特徵となっている。また「公園の位置がわかりやす い」「植物が多い」という回答も多かった。

\section{表 $-6 \quad$ 利用している公園の特徵（複数回答）}

\begin{tabular}{|l|r|}
\hline (1)遊具が多い & 20 \\
\hline (2) 芝生がある & 12 \\
\hline (3)遊べる場所が広い & 26 \\
\hline (4)植物が多い & 18 \\
\hline (5)公園の位置が分かりやすい & 21 \\
\hline (6)水の流れがある & 6 \\
\hline (7)その他 & 13 \\
\hline
\end{tabular}

(単位:学校数)

(5)公園利用に際しての不満

表一７は公園を利用する上での不満であるが，「遊具が少ない」, 「遊べる場所が狭い」が多く回答された。その他，危険を伴う障 害物等が不満の対象となっている。

\section{表 -7 公園利用に際しての不満（複数回答）}

\begin{tabular}{|l|r|}
\hline (1)道具が少ない & 23 \\
\hline (2)順路となるものがない & 5 \\
\hline (3)障害物がある & 6 \\
\hline (4)遊べる場所が狭い & 11 \\
\hline (5)スポーツができない & 5 \\
\hline (6)人とぶつかる & 1 \\
\hline (7)木や枝が突き出して危ない & 4 \\
\hline (8)地面が滑る & 0 \\
\hline (9)一人では何もできない & 3 \\
\hline
\end{tabular}

(単位:学校数)

6)公園を利用しない理由

公園を利用していない盲学校 17 校に，その理由をたずねた結 果，ほとんどの学校は「近くに公園がない」，「公園までの移動に 危険がある」と回答した（表－8）。これらの利用しない理由が 解決した場合について，17 校中 16 校が公園利用を希望している。 このとき，利用に望ましい距離として，「100～250 m」，「250 $500 \mathrm{~m}$ 」，「隣接」を多くあげた（表一9）。また，考えられる主な 利用目的は表一10 のとおりである。「遊具利用」が最も多く, 「自然観察」「運動」,「散歩」等, 現在公園を利用している盲学 校の利用内容と共通している。

\section{表 - 8 公園を利用しない理由（複数回答）}

\begin{tabular}{|l|r|}
\hline$(1)$ 近くに公園がない & 11 \\
\hline$(2)$ 遊ぶ場所が狭い & 1 \\
\hline$(3)$ 公園までの移動に危険がある & 7 \\
\hline$(4)$ 危険な遊具等が多い & 1 \\
\hline (5)他の利用者とのトラブルに不安があ & 0 \\
\hline (6)遊び仲間がいない & 1 \\
\hline
\end{tabular}

(単位:学校数)

\section{表 -9 利用したい公園までの距離（複数回答）}

\begin{tabular}{|l|r|}
\hline (1) 隣接 & 5 \\
\hline (2) $100 \mathrm{~m}$ 以内 & 3 \\
\hline (3) $100 \sim 250 \mathrm{~m}$ & 7 \\
\hline (4) $250 \sim 500 \mathrm{~m}$ & 7 \\
\hline (5) $500 \mathrm{~m} \sim 1 \mathrm{~km}$ & 2 \\
\hline
\end{tabular}

(単位: 学校数)

\section{表 -10 利用する場合の主な利用目的（複数回答）}

\begin{tabular}{|l|r|}
\hline (1)遊具利用 & 13 \\
\hline (2)運動 & 7 \\
\hline (3)散歩 & 7 \\
\hline (4)休憩 & 5 \\
\hline (5)自然観察 & 9 \\
\hline (6)体験学習 & 7 \\
\hline$(7)$ その他 & 1 \\
\hline
\end{tabular}

(単位:学校数)

(7)公園に望むこと

盲学校 71 校に対する公園への要望調査の結果を表-11に示す。 「施設の誘導をわかりやすくしてほしい」が最も多く回答された。 「安全な遊具を増やしてほしい」,「公園周辺の安全性の配慮をし てほしい」等，施設や周辺環境への安全の配慮も望んでいる。

\section{表-11 公園への要望（複数回答}

\begin{tabular}{|l|r|}
\hline (1) 大きな広場をつくってほしい & 3 \\
\hline (2)安全な遊具を増やしてほしい & 13 \\
\hline (3)施設の誘道を分かりやすくしてほし & 15 \\
\hline (4)公園周辺の安全性を配虜してほしし & 10 \\
\hline (5)旬いのする花木を植えてほしい & 11 \\
\hline (6)休養施設がほしいい & 9 \\
\hline (7)その他 & 3 \\
\hline
\end{tabular}

(単位:学校数)

\section{8)公園利用の際の障害物}

公園を利用するときに危険と思われる障害物を，表一 12 に示 した。この結果から「自転車」(15 校) が最も多く, 次いで「犬 や「木や枝」等があげられた。「その他」出入り口の柵, 斜面, 段差，広い空間に突然現れる構造物の危険性があげられた。事前 にその存在が予知しにくいものや，急激な状況変化に対応が難し くなることが示されている。

\section{表-12 公園利用の際の障害物（複数回答）}

\begin{tabular}{|l|r|}
\hline$(1)$ ベンチ & 1 \\
\hline$(2)$ 人 & 0 \\
\hline$(3)$ 木や枝 & 5 \\
\hline$(4)$ 犬 & 7 \\
\hline (5)自転車 & 15 \\
\hline (6)遊具 & 3 \\
\hline (7) その他 & 5 \\
\hline
\end{tabular}

(単位: 学校数) 


\begin{tabular}{|c|c|c|c|c|}
\hline 種類 & 種別 & 配置公園数 & 利用公園数 & 利用率 \\
\hline \multirow{2}{*}{ 基幹公園 } & 住区基幹公園 & 686 & 49 & $74.2 \%$ \\
\hline & 都市基幹公園 & 10 & 2 & $3.0 \%$ \\
\hline \multicolumn{2}{|c|}{ 特殊公園 } & 18 & 3 & $4.5 \%$ \\
\hline \multicolumn{2}{|c|}{ 広域圈公園 } & 1 & 1 & $1.5 \%$ \\
\hline \multicolumn{2}{|c|}{ 緑地 } & 37 & 2 & $3.0 \%$ \\
\hline \multirow{13}{*}{$\begin{array}{c}\text { その他の公園· } \\
\text { 緑地など }\end{array}$} & 保存緑地 & 5 & 0 & $0.0 \%$ \\
\hline & その他の緑地 & 1 & 0 & $0.0 \%$ \\
\hline & 保全地区 & 1 & 0 & $0.0 \%$ \\
\hline & 森林公園 & 1 & 1 & $1.5 \%$ \\
\hline & 墓園 & 1 & 0 & $0.0 \%$ \\
\hline & 特別史跡 & 1 & 1 & $1.5 \%$ \\
\hline & 条例設置公園 & 1 & 1 & $1.5 \%$ \\
\hline & 広場 & 7 & 0 & $0.0 \%$ \\
\hline & 運動場 & 2 & 0 & $0.0 \%$ \\
\hline & 個人所有 & 1 & 1 & $1.5 \%$ \\
\hline & 神社 & 3 & 3 & $4.5 \%$ \\
\hline & 寺 & 1 & 1 & $1.5 \%$ \\
\hline & その他 & $\overline{1}$ & $T$ & $1.5 \%$ \\
\hline \multicolumn{2}{|c|}{ 合計 } & 778 & 66 & $100 \%$ \\
\hline
\end{tabular}

\section{4. 考察}

盲学校の公園利用の実態を調査した結果, 約 $3 / 4$ の盲学校が 公園を利用していた。利用している公園は学校からの距離は500 $\mathrm{m}$ まで，利用時間は 30 60 分程度であった。盲学校にとって公 園は訓練や授業の一環とすることが多いこともわかった。また， 公園を利用する場合，歩行訓練の目的地としていることも多いた め, 公園までの経路の整備も重要であると思われる。公園を利用 しない理由としては，近くに公園がないとする回答が多かったが， 調查の結果では調査対象とした盲学校のほとんどの近接に公園が 設置されていることが示された。そのことから，公園の配置状況 が十分に知られていないか，近接の公園が利用しにくい状況にあ ることが考えられる。盲学校周辺の公園の現状を調べた結果では, 住区基幹公園が利用されている主な公園であった。盲学校の公園 利用を促進するためには, 盲学校の利用しやすい位置にある住区 基幹公園を整備する必要があるといえる。

盲学校に対して公園利用における意見・要望をたずねた結果, 公園内部の施設や周辺環境に対する回答を得られた。施設に対し ては点字誘導ブロック等の誘導施設や安全な遊具の設置や整備へ の要望が多かった。施設への要望の多くは, すでにガイドライン 等に示されてはいるが，利用の主となる住区基幹公園においては 十分に行われていないといえる。その他に公園の清掃や施設修理 など，通常の維持管理が不十分であるとの意見もあった。これら
はほかの身体障害者や健常者の利用においても改善が必要であり， 公園の設置以外に維持管理の体制についても考慮する必要がある といえよう。また, 公園の周辺環境や公園までの経路に関する要 望もあったが, これらの改善については地域住民の理解や自治体 の協力が不可欠と思われる。

\section{5. おわりに}

本報告では盲学校の公園利用についての現状と問題点を明らか にした。盲学校での公園利用は日常的ではない。それは障害者が 利用しやすい公園緑地としての整備が不十分であることにも起因 している。視覚障害者に配慮した公園整備については公園内部の 施設等の整備のみならず, 公園周辺部の環境整備も重視すべきこ とが示唆された。視覚障害者をはじめとする障害者が利用できる 公園整備においては, 彼らの利用上の不具合を解消する必要があ る。それは障害の種類や程度によって様々である。今後は, 彼ら の意見を反映した公園の整備のためのより詳細な調查研究を重ね る必要がある。また，その公園は健常者と障害者が其に利用でき るあのとすべきである。そうすることによって公園はコミュニティ 形成の場, クラブやサークル活動など, さまざまな交流のきっか けの場となり, 彼らの公園利用はいっそう高まっていくものと思 われる。 


\section{参考文献}

1) バリアフリー緑の空間計画検討委員会 (1998)：バリアフリー緑の空間計画 : （社）日本造園学会, $252 \mathrm{pp}$

2 ）浅野房世（1996）：人に優しい公園づ くり : 鹿島出版会, 191pp

3）大熊由紀子ほか（1997）：長寿社会に 対応する公園 : 公園緑地 58(3), 76pp
4) 田口泰彦ほか（1996）: バリアフリー の景：ランドスケープのデザイン NO 3 : マルモ出版, 54-128

5 ）越川秀治（1998）：ケアーガーデン： 都市文化社, $180 \mathrm{pp}$

6 ）建設省都市局公園緑地課（1999）：み んなのための公園づくり：日本公園緑 地協会, $162 \mathrm{pp}$
7 ）永松義博（1985）：全盲者の戸外活動 に関する研究：造園雑誌48(5)，217221

8 ）永松義博（1992）：盲学校生徒の余㗇 活動に関する研究：造園雑誌55(5), 265-270

Summary : In order to know how the blind students use the parks close to the school for the blind, investigations were carried out using questionnaires returned from the schools for the blind in Japan. From putting togather the questionnaires, it became obvious that students in the most of the schools want to utilize the parks. For utilizing the parks, the location of parks close to the school, and the safety of the route to the park were the important conditions. The characteristics of the parks well utilized by the students were wide space in the park, the convenient route to the park, and many plants in the park. In addition, the convenient distance to the park for the blind students was found to be approximately $500 \mathrm{~m}$. 